\title{
THE ORAL HISTORIES OF CANADA'S NORTHERN PEOPLE, ANGLO-CANADIAN EVIDENCE LAW, AND CANADA'S FIDUCIARY DUTY TO FIRST NATIONS: BREAKING DOWN THE BARRIERS OF THE PAST
}

\section{CLAY MCLEOD*}

This article is a call for Canadian Courts to interpret, respect and develop First Nations' rights from the perspective of the aboriginal peoples themselves. Mcleod focuses on the First Nations of the North and how their traditional use of oral histories is profoundly affected by the current Canadian rules of evidence. Indeed, the whole concept of the adversarial system. a system based on Western European culture. assumptions, and principles, and its effectiveness in determining the "truth" is shown to be inadequate at addressing the concept of the "truth" as defined by the First Nations. Mcleod exposes an inexcusable "cross-culnural clash" occurring within Canadian courtrooms that is causing the rules of evidence to become tools of oppression preventing the oral histories of the First Nations from properly being admitted and given due weight. Mcleod continues, however. to suggest ways by which some of the rules of evidence could be utilized so as to effectively allow the aboriginal people the opportunity of presenting their oral histories to the Courts and having them accepted as being valid and trustworthy.
Le présent article exhorte les tribunaux canadiens à interpréter, à respecter et à élaborer les droits des premières nations dans la perspective des peuples autochtones eux-mêmes. McLeod examine les premieres nations du Nord et en quoi l'utilisation traditionnelle des histoires orales est profondément marquée par les règles canadiennes de la preuve. En fait, tout le concept du système adversarial - qui est fondé sur la culuure, les hypothèses et les principes issus de l'Europe de l'Ouest, et son rôle quand il s'agit de déterminer la "vérité" - s'avère inefficace lorsqu'il est appliqué au concept de vérité tel que le définissent les premières nations. McLeod dénonce le choc inter-culturel inexcusable qui se produit au sein des tribunaux canadiens. II transforme les règles de la preuve en instruments d'oppression et empêche que les histoires orales des premières nations ne soient reçues et considérées à leur juste valeur. McLeod suggère cependant des modalités qui autoriseraient à appliquer certaines règles de la preuve permettant aux peuples autochtones de présenter efficacement leurs histoires orales devamt les cours et de les faire accepter comme valides et dignes de foi.

\section{TABLE OF CONTENTS}

I. INTRODUCTION

II. FIRST NATIONS' ORAL HISTORIES $\ldots \ldots \ldots \ldots \ldots \ldots \ldots 1278$

A. THE LEGAL RIGHTS OF CANADA'S

FIRST NATIONS . . . . . . . . . . . . . . . . 1278

B. THE HISTORY OF CANADA'S

FIRST NATIONS . . . . . . . . . . . . . . . . . . . . . 1279

C. THE USE OF LITERACY AS A

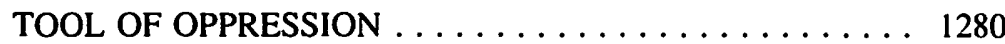

D. ANGLO-CANADIAN EVIDENCE LAW $\ldots \ldots \ldots \ldots \ldots 1280$

III. CANADA'S FIDUCIARY DUTY TO

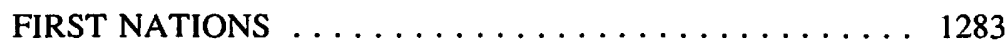

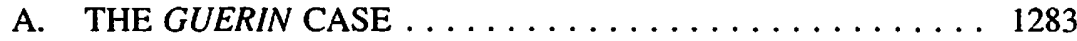

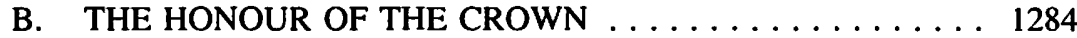

Winner of the William Morrow Essay Contest, January 6, 1992. I would like to acknowledge the support of the Treaty and Aboriginal Rights Research Department of the Indian Association of Alberta. It was during my employment there as an Indian Management Assistance Program Consultant in 1991 that I was first exposed to the ideas that later became the basis of this paper. 


\section{ANGLO-CANADIAN EVIDENCE LAW:}

ANOTHER LOOK . . . . . . . . . . . . . . 1284

IV. CONCLUSION ........................ 1289

\section{INTRODUCTION}

Five hundred years ago, Europeans venturing across the Atlantic Ocean came across two continents inhabited by people we have come to call Indians. They are America's First Nations people. They had, and still have, vibrant cultures and a strength that will not be denied. Since those first European explorers stumbled upon the Americas, North America has been a stage upon which a complex story of "cross-cultural contact" has been played out.' In that time, the European newcomers have experienced many new and unfamiliar cultures, and North America's indigenous peoples have experienced many challenges and hardships. Unfortunately, much of the historic course of this cross-cultural dynamic has been determined by the prejudices and ethnocentric notions of the European newcomers. As we celebrate the five-hundredth anniversary of the "discovery" of the Americas by those first European explorers, it is important that we look for ways to change the substance of the cross-cultural dynamic which pertains in North America.

Today, the cross-cultural dynamic that has defined the last five hundred years of North and South American history continues to unfold in Canada's northern territories. In many ways, the interaction between northern aboriginal and European cultures is still young. Mistakes that have characterized the relations between North and South America's indigenous peoples and the European newcomers elsewhere in the Americas do not have to be repeated in Canada's north.

As the indigenous peoples of Canada's north struggle to retain their culture and their strong bond with the land that is their home, the lawmakers and judges in the South will play a large part in the determination of the fate of Canada's northern First Nations. Many new developments in Canadian law hold the potential to make the future of Canada's relationship with its First Nations in the north a positive experience for both cultures, but it remains to be seen whether the promise of these new developments will be realized.

Communication between the two cultures is essential if any positive relationship between the indigenous peoples of Canada's north and the Canadian lawmakers in the south is to grow out of the cross-cultural contact that will define the future of Canada's north.

Robert N. Clinton, "The Curse of Relevance: An Essay On the Relationship of Historical Research To Federal Indian Litigation" (1986) 28 Arizona L. Rev. 29 at 30. 


\section{FIRST NATIONS' ORAL HISTORIES}

\section{A. THE LEGAL RIGHTS OF CANADA'S FIRST NATIONS}

Canadian law recognizes that First Nations have certain rights. According to Canadian law, the rights of First Nations stem from two main sources, the common law doctrine of aboriginal rights and Treaties between the English Crown and First Nations. The common law doctrine of aboriginal rights attributes rights to indigenous peoples by virtue of their original use and occupancy of their traditional lands. ${ }^{2}$ Canadian law also recognizes that First Nations have rights which stem from Treaties negotiated with the English Crown. Treaties between the English Crown and First Nations define the rights of First Nations parties by their terms. At the time they were made, the European Nations regarded the aboriginal parties to the Treaties as "independent nations." ${ }^{3}$ Accordingly, the English Crown entered into these treaties "with the intention of creating mutually binding obligations which would be solemnly respected." ${ }^{14}$ In 1982, existing aboriginal and treaty rights were recognized and affirmed by s. 35 of the Constitution Act, 1982.

It is essential that courts determining the rights of First Nations consider the situation from the aboriginal perspective, whether the rights at issue stem from the common law doctrine of aboriginal rights or from Treaties negotiated between the English Crown and the aboriginal group involved. In cases where the common law doctrine of aboriginal rights is at issue, the history of the particular aboriginal group must be considered:

Claims to aboriginal title are woven with history, legend, politics and moral obligations. If the claim of any Band in respect of any particular land is to be decided as a justiciable issue and not a political issue it should be so considered on the facts appurtenant to that Band and to that land, and not on any global basis.6

Similarly, in cases where the rights of First Nations are determined by the terms of a Treaty, courts are obliged to consider the aboriginal understanding of the effect of the Treaty. ${ }^{7}$

For a court to consider the history of a particular Band or the understanding of an aboriginal group as to the effect of a Treaty, it needs to consider the oral history of the aboriginal group involved. It is impossible for a court to undertake the necessary historical inquiries in aboriginal and Treaty rights cases without having regard to the oral histories of Canada's First Nations.

Calder et al. v. Attorney General of British Columbia (1973), 34 D.L.R.(3d) 145 (S.C.C.).

Attorney General of Quebec v. Sioui, [1990] 3 C.N.L.R. 127 (S.C.C.) at 146.

Simon v. R. (1985), [1986] I C.N.L.R. 153 (S.C.C.) at 166.

Constitution Act, 1982, being Schedule B of the Canada Act 1982 (U.K.), 1982, c. 11.

Kruger and Manual v. R. (1977), 75 D.L.R.(3d) 424 (S.C.C.) at 437.

Nowegijick v. R., [1983] 2 C.N.L.R. 89 (S.C.C.) at 94. 


\section{B. THE HISTORY OF CANADA'S FIRST NATIONS}

Before the coming of the Europeans, Canada's First Nations had no written history; their history was recorded in their oral traditions. ${ }^{8}$ To a society which does not keep written records, oral traditions are of the utmost importance. They act as a repository of historical knowledge for a culture, and they express the values and mores of the culture. ${ }^{9}$ Oral traditions reflect cultural ideas about the nature of knowledge and reality. For Canada's First Nations, oral traditions have been one of society's fundamental institutions:

The native American cultures preserved their oral traditions with fidelity, and many valued oratory and drama in speech. The native languages were spoken - as many are spoken even today - with precision and no slovenly quality. The oral traditions of the New World reflect a vast unwritten literature. ${ }^{10}$

In 1973, oral histories were brought before the Supreme Court of the Northwest Territories in a trial concerning the filing of a caveat based on the existence of aboriginal rights of First Nations people in the Northwest Territories. Morrow J. said this:

In addition, oral evidence from many of the chiefs who actually signed the caveat as well as testimony from Indians and others still living who remembered the treaty-making negotiations, was also brought forward... I think almost every member of the court party felt that for a short moment the pages of history were turned back and we were privileged to relive the treaty-negotiating days in the actual setting... There is no doubt in my mind that their testimony was the truth and represented their best memory of what to them at the time must have been an important event."

The oral histories of Canada's First Nations are usually maintained by the elders in the community; in First Nations culture, elders are accorded the highest respect. Because of the respect accorded to the keepers of oral histories, the oral histories themselves are authoritative in First Nations culture. Moreover, the oral histories of First Nations have been passed from generation to generation, and they have been validated by each generation in the chain; the result is that oral histories are "enclothe[d]... with a cloak of trustworthiness."'2

8. Indians had no written literature; their myths, legends, tales, and fables were passed down orally by each generation." See Merwyn S. Garbarino, Native American Heritage (Toronto: Little, Brown and Company, 1976) at 370.

9. Oral traditions can "[reaffirm] the traditional social structure and [unite] 'then' with 'now', the heroic ancestors with their descendants who are members of the audience." See Viv Edwards \& Thomas J. Sienkewicz, Oral Cultures. Past and Present (Oxford: Basil Blackwell Ltd., 1990) at 33. Robert F. Spencer et al., The Native Americans, 2d ed. (San Francisco: Harper \& Row Publishers. 1977) at 38.

11. Re Paulette et al. and Registrar of Titles (No. 2) (1973), 42 D.L.R.(3d) 8 (N.W.T. S.C.) at 12-13, rev'd Re Paulette et al. and Registrar of Land Titles (1975), 63 D.L.R.(3d) I (N.W.T. C.A.), aff'd Paulette et al. v. R. (1976), 72 D.L.R.(3d) 61 (S.C.C.). 


\section{THE USE OF LITERACY AS A TOOL OF OPPRESSION}

"Attempted discourse between cultures may create conflict, ambiguity, even oppression."13 It can certainly be said that the discourse between the European newcomers to the Americas and the indigenous peoples of those continents has resulted in conflict and oppression.

In the period when the Portuguese and Spanish, followed by other European nationalities, began the exploration and conquest of the entire world, there began a period of intensified confrontation and frequent conflict in which the literate societies of Europe - armed not only with guns and cannons, but with their printed books of religious and legal commandments - sought to subdue non-literate societies of Africa and the Americas. ${ }^{14}$

There are many instances of the use of literacy as a tool of oppression in the history of Anglo-Canadian law. A recent case illustrates this quite profoundly. A First Nations group asserting that they had aboriginal title to an island in British Columbia sought to prevent the logging of that island in order to preserve its environment. In discussing the right of the plaintiff logging company to log on the island, the judge said this:

Armed with all the necessary pieces of paper in the form of title and tenure documents, permits, licences, and other authorizations and approvals, on November 21, 1984 MacMillan Bloedel sent a seventeen man crew by boat to Meares Island to start work. ${ }^{\text {Is }}$

This choice of words shows how documents and literacy have been used as weapons of oppression in the Canadian courts.

The law of evidence has also been used to oppress First Nations. It is founded upon the principles of western European culture, not those of native American culture. This means that evidence which is valuable in the latter context has often been overlooked in the former context. This has been the result of ethnocentric concepts in western culture which have led to a devaluation of the oral histories of Canada's First Nations in the legal system.

\section{ANGLO-CANADIAN EVIDENCE LAW}

In Canadian law, a party must prove that it is entitled to some sort of legal relief before a court will make an order in favour of that party. The rules of evidence govern how parties to an action can go about proving facts to the court. The rules of evidence applied

13. Robin Ridington, "Cultures In Conflict: The Problem of Discourse" in W. H. New, ed., Native Writers and Canadian Writing (Vancouver: UBC Press, 1990) 273 at 278.

14. William Bright, American Indian Linguistics and Literature (New York: Mouton Publishers, 1984) at 153. "Finally, I note that, in the confrontation between literate and non-literate socicties - which continues through history down to the present day - writing has often been used by literate groups as a tool of oppression and discrimination, and ultimately as a weapon to destroy the values of nonliterate peoples." See ibid. at 150.

15. MacMillan Bloedel Ltd. v. Mullin et al., [1985] 2 C.N.L.R. 26 (B.C. S.C.) at 31. 
by the Canadian courts have been developed in the shadow of the adversary system. Therefore, those rules of evidence are grounded in the assumptions and principles at the heart of the adversary system. Those assumptions and principles are, in turn, grounded in western European culture.

In the adversary system, an impartial decision maker resolves disputes between parties after hearing each party represent the merits of their position in a biased manner. ${ }^{16}$ It "has been justified over the years by many lawyers as capable of promoting the finest approximation of the truth." ${ }^{17}$ The two ideas at the root of the adversary system are that individuals are self interested and will attack any position contrary to their own interests and that the truth will become apparent as a result of the clash of opposite ideas.

However, the "truth" that the adversary system approximates is a western European cultural idea; the idea of "truth" at the bottom of the adversary system is not the same as the idea of "truth" in First Nations culture. ${ }^{18}$ The value of the adversary system as a method of undertaking historical inquiries is highly suspect. "Thrusting the scholar into the rough and tumble adversary process may make the ultimate illumination of the past less, rather than more, likely."19

To understand how the Anglo-Canadian law of evidence has been used as a tool of oppression, it is helpful to examine how Canadian courts have applied the rules of evidence to oral history evidence brought before courts by First Nations litigants.

\section{The Hearsay Rule}

Hearsay is defined as an out of court statement which a party tries to use as proof of its contents. ${ }^{20}$ Hearsay is generally considered to be inadmissible as evidence. The rule against hearsay has three justifications. Witnesses testifying in court take an oath; theoretically, this guarantees that they will be worthy of trust. Also, when witnesses testify in court, the decision maker has an opportunity to assess the demeanour of witnesses and make inferences about their trustworthiness. Most importantly, in-court testimony affords the opposite party an opportunity for cross-examination.21

However, if it satisfies the test for hearsay exceptions, Canadian courts admit second hand evidence in spite of the hearsay rule. It must have a guarantee of trustworthiness, and the circumstances of the case must make it necessary for the court to consider the Limited, 1984) at 1.

17. Ibid. at 1 .

18. The "notion of 'truth' itself is culture bound and cannot correspond to the 'historical truth' familiar to the historical scholar." See Jan Vansina. Oral Tradition As History (Madison: The University of Wisconsin Press, 1985) at 83. historical inquiries, because it "pushes historical analysis into extreme positions." See ibid. at 38. Adrian Keane, The Modern Law of Evidence, 2d ed. (London: Butterworths, 1989) at 8.

21. Deslisle, supra, note 16 at 202. 
hearsay evidence. ${ }^{22}$ Although Canadian law classifies oral history evidence as hearsay, courts have considered oral history evidence in making decisions. The Supreme Court of Canada made an exception to the hearsay rule in the Simon case on the basis of necessity:

The Micmacs did not keep written records. Micmac traditions are largely oral in nature. To impose an impossible burden of proof would, in effect, render nugatory any right to hunt that a present-day Shubenacadie Micmac Indian would otherwise be entitled to invoke based on this treaty. ${ }^{23}$

However, even when Canadian courts make an exception to the hearsay rule and consider oral history evidence, they usually find some other rule of evidence which they can use to devalue the oral history evidence.

\section{The Best Evidence Rule}

According to the best evidence rule, courts frown upon the use of "inferior evidence" by parties, as opposed to "the best evidence available" to them. ${ }^{24}$ Canadian courts have applied this rule to oral history evidence. In the Bear Island case, Steele J. asserted that oral history "may be contradicted by factual records."

Steele J. let his ethnocentric biases in favour of the literacy of his own culture blind him to the value of oral histories; oral histories are just as capable of contradicting "factual records" as "factual records" are of contradicting oral history. In the dissent in the Horseman case, Wilson J. also fell victim to her own ethnocentric biases. She asserted that oral history evidence regarding the meaning of Treaties is relevant "where it confirms the archival evidence with respect to the meaning of the treaty." ${ }^{26}$ By regarding oral history evidence as a source of confirmation of archival evidence Wilson J. implicitly denies that it is useful as a primary source of historical knowledge.

\section{Weight}

"The weight of evidence is its cogency or probative worth in relation to the facts in issue." ${ }^{27}$ Even if a court admits a piece of evidence, it may refrain from attaching any weight to the evidence if it feels that the evidence has no probative value. Canadian courts use the concept of weight to deny the value of oral history evidence. Consider the comments of McEachern C.J.S.C. in the Delgamuukw case:

22. Ibid. at $219-220$.

23. Supra, note 4 at $171-172$.

24. Keane, supra, note 20 at 20.

25. Altorney General for Ontario v. Bear Island Foundation, [1985] 1 C.N.L.R. 1 (Ont. S.C.) at 17, aff'd [1989] 2 C.N.L.R. 73 (Ont. C.A.). An appeal to the Supreme Court of Canada was denied earlier this year in an unreported decision.

26. Horseman v. R., [1990] 3 C.N.L.R. 95 (S.C.C.) at 111.

27. Keane, supra, note 20 at 20. 
Admissibility and weight of evidence are two completely different concepts. While I have not been troubled by the former, the doubts I have about the latter preclude me from treating the adaawk and kungax [the oral histories before the Court in this case] as direct evidence of facts in issue in this case except in a few cases where they could constitute confirmatory proof of early presence in the territory. ${ }^{2 \pi}$

Even when Canadian courts have admitted oral history evidence, they have allowed their ethnocentric biases to blind them to the value of oral history and consequently have disregarded the oral history evidence as a trustworthy source of historical information.

\section{The Parole Evidence Rule}

When an agreement is reduced to writing, the court will interpret the writing to determine the terms of the agreement;

The normal rule with respect to interpretation of contractual documents is that extrinsic evidence is not to be used in the absence of ambiguity: nor can it be invoked where the result would be to alter the terms of a document by adding to or subtracting from the written agreement. ${ }^{29}$

This rule was applied to a Treaty in the Horse case. ${ }^{30}$ In the Horse case, Estey J. did not consider the transcript of the negotiations surrounding Treaty No. 6 when he interpreted the meaning of the written terms, because he did not feel that the written terms were ambiguous. ${ }^{31}$

The Horse case, the Delgamuukw case, and the Bear Island case are all examples of how the law of evidence has been used by Canadian courts as a tool of oppression.

\section{CANADA'S FIDUCIARY DUTY TO FIRST NATIONS}

\section{A. THE GUERIN CASE}

A relatively recent development in the law is the idea of a fiduciary duty owed to aboriginal peoples by the government in certain circumstances. This concept is based on the history of common law aboriginal rights. The origin of this development was the Guerin case. ${ }^{32}$ In that case, the Court found that the government breached the fiduciary duty it owed to the Musqueam Band in British Columbia. The Court discovered the fiduciary duty in the historic nature of Indian title.






\section{B. THE HONOUR OF THE CROWN}

In the Sparrow case, the Supreme Court extended the reach of the fiduciary concept it had introduced in Guerin:

[T]he Government has the responsibility to act in a fiduciary capacity with respect to aboriginal peoples.

The relationship between the Government and aboriginals is trust-like, rather than adversarial, and contemporary recognition and affirmation of aboriginal rights must be defined in light of this historic relationship. ${ }^{3.3}$

The historic reluctance of Canadian courts to consider First Nations' oral histories as persuasive evidence in legal proceedings is not consistent with the "trust-like" relationship that, according to the law, exists between Canada and First Nations peoples.

In Sparrow, the Supreme Court of Canada talked about "holding the Crown to a high standard of honourable dealing with respect to the aboriginal peoples of Canada. ${ }^{\text {"34 }}$ If the Crown is to deal honourably with First Nations, it must consider the historical information contained in oral histories when it determines the legal rights of First Nations. Only then can discourse between the Canadian legal community and First Nations be powerful and enabling. Canadian courts must "understand [aboriginal] discourse and how it relates to the discourse of [their] own legal tradition." ${ }^{35}$

\section{ANGLO-CANADIAN EVIDENCE LAW: ANOTHER LOOK}

It is true that, in the past, Canadian courts have used the rules of evidence as tools of oppression; they have used concepts like weight and rules like the parole evidence rule to devalue the oral histories of First Nations. Canadian judges have proclaimed that they decide cases "in accordance with legal, not cultural principles. ${ }^{36}$ Such statements reflect an ethnocentric vanity verging on racism. The "legal principles" so adored by Canadian judges are nothing other than the cultural principles of the European newcomers to this continent. In the past, the rules of evidence have been animated by the ethnocentric notions of judges. However, with a little effort, the rules of evidence can be applied in a culturally unbiased manner.

\section{The Parole Evidence Rule, Revisited}

In the Horse case, Estey J. alluded to an exception to the parole evidence rule. When there is ambiguity in the written terms of a Treaty, "extraneous interpretive material" can be considered by the court. ${ }^{37}$ Because of the historical context of the treaties arranged between the British Crown and First Nations, it can be said that the terms of all Treaties are ambiguous:

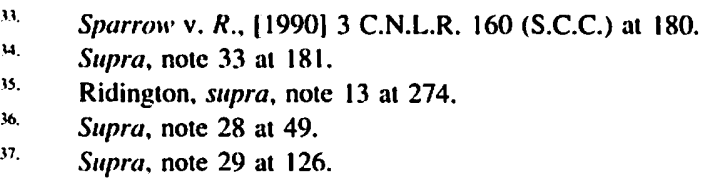


These treaties were the product of negotiation between very different cultures and the language used in them probably does not reflect, and should not be expected to reflect, with total accuracy each party's understanding of their effect at the time they were entered into. ${ }^{38}$

In $R$. v. Taylor and Williams, ${ }^{39}$ evidence about the oral traditions of the Indian tribes involved was considered admissible. ${ }^{40}$ The oral portions of that treaty were considered to be "as much a part of that treaty as the written articles of the provisional agreement." ${ }^{41}$

Cases on Indian and aboriginal rights can never be determined in a vacuum. It is of importance to consider the history and oral traditions of the tribes concemed, and the surrounding circumstances at the time of the treaty, relied on by both parties, in determining the treaty's effect. ${ }^{42}$

The recent Supreme Court of Canada Sioui case adopted the statements of the Ontario Court of Appeal in Taylor. ${ }^{43}$

The oral histories of First Nations are relevant to the interpretation of treaties, because they contain information about the historical context of the treaty and they are a source of information about the aboriginal perspective about the effect of the treaties.

\section{Judicial Notice}

Judicial notice is the term used to describe the practice of courts using their knowledge about the world to make decisions without requiring the parties to the action to prove the things known by the court. ${ }^{44}$

Supra, note 26 at 109 . "Treaties must be given the effect the signatories obviously intended them to have at the time they were entered into even if they do not comply with today's formal requirements... Nor should they be undermined by the application of the interpretive rules we apply today to contracts entered into by parties of equal bargaining power." See supra, note 26 at 109. [1981] 3 C.N.L.R. 114 (Ont. C.A.).

Supra, note 39 at 120.

Supra, note 39 at 117.

Supra, note 39 at 120.

Supra, note 3. This case also limited the application of Horse. "However, a more flexible approach is necessary as the question of the existence of a treaty... is generally closely bound up with the circumstances existing when the document was prepared." See supra, note 3 at 143. "The historical context, which has been used to demonstrate the existence of the treaty, may equally assist us in interpreting the extent of the rights contained in it." See supra, note 3 at 155.

"Certain matters are so well known in the community or so casily determinable with certainty as to be indisputable. This knowledge may be in the possession of the trier of fact at the very beginning of the trial and need not then be proved according to the normal rules of evidence. The party who has the burden of proof on the issue may have to call on the trier to judicially notice the fact when it comes time to analyze the question. The trier may feel the need to inform itself of the fact, but when it does so it need not feel itself confined by the rules of evidence." See Deslisle, supra, note 16 at $90-91$. 
"Taking judicial notice of historical records and historical facts has long been a practice of the common law."45 The most important application of this principle to the context of First Nations litigation was in the Calder case. In that case, the Supreme Court of Canada stated that in order to consider the issues involved in that case, it was necessary to study the records of history:

The Court may take judicial notice of the facts of history whether past or contemporaneous..., and the Court is entitled to rely on its own historical knowledge and researches. ${ }^{46}$

Recently, Lambert J.A., of the British Columbia Court of Appeal, considered archival records when interpreting the terms of the treaty involved in $R$. v. Bartleman. ${ }^{47}$ By considering records of history which were not led at trial, Lambert J.A. was:

taking judicial notice of indisputable, relevant, historical facts by reference to a readily obtainable and authoritative source, in accordance with the ordinary principles of judicial notice. ${ }^{48}$

In the above instances, the concept of judicial notice was applied to written historical records. However, statements in recent cases such as Sparrow and Sioui which underline the importance of considering the aboriginal perspective must be taken into account. They open the door for the application of the concept of judicial notice to the information represented by First Nations' oral histories. Moreover, recent cases illustrate the flexibility of the concept of judicial notice. ${ }^{49}$

\section{A Hearsay Exception}

Recent developments in the law enable one to argue not only that oral histories should be admitted in evidence as an exception to the hearsay rule, but that courts should attach an appropriate amount of weight to them. The principles underlying the Supreme Court

45. M. H. Olgilvie, "Historical Documents and Historical Facts - Indian Treaty Rights" (1986) 64 Can. Bar Rev. 183 at 183.

46. "The assessment and interpretation of the historical documents and enactments tendered in evidence must be approached in the light of present-day research and knowledge disregarding ancient concepts formulated when understanding of the customs and culture of our original people was rudimentary and incomplete and when they were thought to be wholly without cohesion, laws or culture, in effect a subhuman species." Sec supra, note 2 at 169.

47. [1984] 3 C.N.L.R. 114 (B.C. C.A.).

48. Supra, note 47 at 117 . However, it is important to note that the conduct of Lambert J.A. in Bartleman has been criticized by M. H. Olgilvie. Olgilvie's criticisms centre around the fact that judicial notice was taken of things that the parties did not bring to the court's attention. Olgilvie's contention is that courts considering evidence led by the parties have confused this consideration with the concept of judicial notice. Although they have academic validity, these subtle criticisms are not important in this context. See M. H. Olgilvie, supra, note 45.

49. The Supreme Court of Canada applied the concept of judicial notice to knowledge contained in text books about the battered wife syndrome in the recent case of $R$. v. Lavallee, [1990] I S.C.R. 852. The Supreme Court of Canada also took judicial notice of the inherent trustwonthiness of young persons in the recent case of $R$. v. Khan (1990), 59 C.C.C.(3d) 92 (S.C.C.). These decisions will be discussed further below. 
of Canada's decision in the recent $K h^{50}{ }^{50}$ case can be applied to the documentation of oral histories.

The Khan case involved statements made by a young child to her mother with respect to the actions of the accused. These statements were classified as hearsay, because the child made them out of court. The court admitted the hearsay evidence of the child's statements to her mother, because it was considered both necessary and trustworthy. ${ }^{51}$

The court discussed the hearsay rule:

The hearsay rule has traditionally been regarded as an absolute rule, subject to various categorics of exceptions, such as admissions, dying declarations, declarations against interest and spontaneous declarations ... this approach ... has frequently proved unduly inflexible in dealing with new situations and new needs in the law. This has resulted in courts in recent years on occasion adopting a more flexible approach, rooted in the principle and policy underlying the hearsay rule rather than the strictures of traditional exceptions. $\$ 2$

The Court recognized that children are inherently trustworthy, and based an exception to the hearsay rule on that fact. ${ }^{53}$

Analogous logic could quite easily be applied to oral histories. The situation facing First Nations litigants today is a "new situation," to use the words of the Supreme Court in Khan, and the needs expressed in Sparrow, Guerin, and Sioui are certainly "new needs in the law."

Comparing oral history evidence to other kinds of evidence which have been admitted as exceptions to the hearsay rule illustrates that oral history evidence is a trustworthy source of historical information, even according to the rules of evidence. Two exceptions to the hearsay rule are particularly informative, the ancient document rule and the rule pertaining to declarations about public rights made by persons who are now deceased.

The ancient document rule allows statements made in documents which are over thirty years old to be admitted as evidence tending to prove their assertions as long as the document was formally executed, is produced from proper custody, and is free from suspicion. ${ }^{54}$ Ancient documents are regarded as trustworthy because they are old;

so. Supra, note 49.

51. "I conclude that hearsay evidence of a child's statement on crimes committed against the child should be received, provided that the guarantees of necessity and reliability are met, subject to such safeguards as the judge may consider necessary and subject always to considerations affecting the weight that should be accorded to such evidence." See supra, note 49 at 106.

5. Supra, note 49 at 100.

53. "Moreover, the evidence of a child of tender years on such matlers may bear its own special stamp of reliability." See supra, note 49 at 101.

54. Delgamuukw' v. R., [1990] I C.N.L.R. 20 (B.C. S.C.) at 23. In Alberta, for a document to fit into the ancient documents rule, it only has to be twenty years old. Sce Alberta Evidence Act, R.S.A. 1980, c. A-21, s. 62. 
because of their age, they are "regarded as authority." ${ }^{\text {"5s }}$ The basis of the rule is the assumption that there have been opportunities over the document's life time for persons to criticize the document, and the fact that the document was made before litigation was contemplated also lends credibility to its assertions.

The same logic applies to oral histories, most of which are even older than ancient documents. They have been passed down through generations of First Nations people, and there have been many opportunities for their detractors to speak their views:

Elders know that the important parts of their history, contained within the ada'ox or expressed through the kungax /the oral histories of the Gitksan and Wet'suwet'en people] have been told, heard and acknowledged many many times. This accumulated validation lies behind the present day chiefs insistence that a particular story is true and is not anything like mere hearsay. ${ }^{56}$

Courts also admit hearsay evidence about declarations made by deceased persons about "ancient rights of a public or general nature." ${ }^{57}$ This kind of evidence is considered trustworthy because of "the public nature of the rights, which tends to preclude individual bias and lessen the danger of misstatements by exposing them to constant contradiction." ${ }^{\text {S8 }}$ Oral histories are similarly exposed to "constant contradiction."

In Khan, the Court recognized the trustworthy nature of statements made by children; statements made by Indian elders with respect to their oral histories deserve the same recognition. Such statements are made within a cultural context which guarantees their trustworthiness. Statements made by Indian elders about oral history bear their own "special stamp of reliability."

\section{Expert Evidence}

"The rules of evidence permit experts to give evidence in the courtroom to provide opinions and facts helpful to the determination of issues in dispute. ${ }^{.60}$ Expert evidence has been important in many cases involving First Nations. Expert evidence is important in the context of oral history, because experts can base their opinions on information gained by them from oral histories.

55. Deslisle, supra, note 16 at 252.

so. M. Jackson et al., "The Address of the Gitksan and Wet'suwet'en Hereditary Chiefs to Chief Justice McEachern of the Supreme Court of British Columbia" [1988] I C.N.L.R. 17 at 35.

57. M.N. Howard, Peter Crane \& Daniel Hochberg, Phipson On Evidence (London: Sweet \& Maxwell, 1990) at 736. This rule was applied to First Nations oral histories in the Delgamumkw case. McEachem C.J.S.C. concluded that "reputations about interests in land and boundaries are admissible." See Uukw et al. v. R. (1987), [1988] I C.N.L.R. 188 (sub nom. Delgamuukw v. R.) (B.C. S.C.) at 204. See also supra, note 28 at 47.

sk. Howard, supra, note 57 at 736.

59. Supra, note 49 at 101 . The Dick decision echoes this assertion. See supra, note 12.

6. "Normally, evidence in the form of opinions is regarded as inadmissible but the courts allow experts to give opinion evidence because of the 'greater reliability' of opinions from those with 'special' skill or training." See Ian R. Freckelton, The Trial of the Expert: A Study of Expert Evidence and Forensic Experts (Melbourne: Oxford University Press, 1987) at 17. 
When using oral histories as the basis of an expert's opinion, it is important to consider the "basis rule." This rule says that "expert opinions are excluded from evidence if their basis either is not admitted or is not admissible in evidence." ${ }^{61}$ However:

much of experts' testimony must necessarily be based upon what other people have said to them, what they have leamed from the work of others, and what they have read in theoretical writings of those in that profession. ${ }^{62}$

This means that the basis rule cannot be stringently applied. ${ }^{63}$

In the recent Lavallee case, the Supreme Court of Canada made the following propositions with respect to expert evidence:

1. An expert opinion is admissible if relevant, even if it is based on second-hand evidence.

2. This second-hand evidence (hearsay) is admissible to show the information on which the expert opinion is based, not as evidence going to the existence of the facts on which the opinion is based.

3. Where the [expert] evidence is comprised of hearsay evidence, the problem is the weight to be attributed to the opinion.

4. Before any weight can be given to an expert's opinion, the facts upon which the opinion is based must be found to exist. ${ }^{\text {th }}$

With respect to the fourth proposition, the Court said that "there must be admissible evidence to support the facts on which the expert relies before any weight can be attributed to the opinion." ${ }^{65}$ However, it is not the case that every single fact relied upon by the expert must be admissible as evidence. ${ }^{66}$

It is clear that the principles and policies underlying Anglo-Canadian evidence law would not be offended by a court taking oral history evidence into account in a Treaty or aboriginal rights case. All that is needed is for judges to apply the rules of evidence without giving rein to ethnocentric biases which devalue the traditions of oral cultures.

\section{CONCLUSION}

When cases involving the rights of northern and other First Nations come before the Canadian courts, it is necessary for the court to take the aboriginal perspective of the situation into account if a just decision is to be the result. However, in the past, Canadian

61. "However, the expert is in no different position as to hearsay evidence - he or she cannot assert that what someone else said is the truth." See ibid.

62. $\quad$ Ibid. at 83.

63. The rule was relaxed in the Australian Milirrpum case. "In my opinion such evidence is not rendered inadmissible by the fact that it is based partly on statements made to the expert by the aboriginals." See Milirrpum v. Nabalco Pty. LId. (1971), 17 F.L.R. 141 at 161. This was quoted in Freckelton, supra, note 60 at 86.

64. Supra, note 49 at 893.

65. Supra, note 49 at 895.

66. Supra, note 49 at 896 . 
courts have used the law of evidence to devalue the information contained in First Nations' oral histories, thus denying First Nations litigants the opportunity to put relevant historical information before the court.

The rules of evidence have been applied to the oral histories of First Nations in a biased, ethnocentric fashion, ignoring the cultural context of the oral histories. This is not consistent with the fiduciary relationship that exists between Canada and its original peoples. For Canada to be true to its fiduciary obligations, it must listen to its First Nations peoples, and Canadian courts must endeavour to understand their cultures.

To understand the cultures of First Nations is to acknowledge the validity and the worth of oral histories as a source of historical information. When the rules of evidence are applied in a culturally relevant, unbiased fashion, it becomes clear that oral histories can be admitted as evidence and that it is proper for courts to attribute a significant amount of weight to the evidence represented by the oral histories of our First Nations. Then maybe, just maybe, truth and justice will prevail. 